ОСОБЛИВОСТІ ПРОЦЕСУ ПІДВИЩЕННЯ КВАЛІФІКАЦІЇ ВЧИТЕЛІВ ЗАКЛАДІВ ЗАГАЛЬНОЇ СЕРЕДНЬОЇ ОСВІТИ У СФЕРІ ОХОРОНИ Й ЗАХИСТУ ПРАВ ІНТЕЛЕКТУАЛЬНОЇ ВЛАСНОСТІ

\title{
PECULIARITIES OF THE PROCESS OF IMPROVING THE QUALIFICATION OF TEACHERS OF GENERAL SECONDARY EDUCATION IN THE FIELD OF PROTECTION OF INTELLECTUAL PROPERTY
}

У статті проаналізовано сучасні тендениії процесу підвищення кваліфікації вчителів закладів загальної середньої освіти в умовах диверсифрікації освітніх послуг після оновлення законодавства в освітній сфері. Приділено увагу особливостям підвищення кваліфрікації педагогічних працівників у галузі охорони і захисту прав інтелектуальноі власності для фрормування профресійно значущої компетентності. Доведено необхідність формування компетентності у галузі охорони і захисту прав інтелектуальної власності, що дасть змогу вчителю вести професійну діяльність на високому рівні з дотриманням норм чинного законодавства стосовно охорони авторських та суміжних прав, забезпечувати дотримання норм академічної доброчесності під час освітнього прочесу й охороняти авторські права на результати власної творчої діяльності та дослідницької діяльності учнів. Наведено концептуальну модель підвищення квалісрікаціі вчителів закладів загальної середньої освіти у галузі інтелектуальної власності з урахуванням сучасних освітніх викликів, вимог суспільства до профресійного рівня вчителя та модульного принципу побудови планів підвищення квалісрікації. Висвітлено можливі шляхи підвищення кваліфікації вчителів у галузі інтелектуальної власності. Виявлено, що мобільність учителів стосовно вибору змістовного наповнення планів та вибору установ підвищення кваліфрікації дає змогу раціонально розподілити час для заповнення прогалин у сорері охорони і захисту прав інтелектуальної власності в заклад середньої освіти. Обірунтовано застосування технологічного підходу до підвищення квалісрікації в окресленій галузі та наведено «Технологію фрормування компетентності у сорері охорони та захисту прав інтелектуальної власності вчителів в процесі підвищення квалісрікації». Установлено, що для ведення ефективної педагогічної діяльності необхідно формувати професійно значущу компетентність у галузі охорони і захисту прав інтелектуальної власності протягом усього професійного розвитку педагога, що дає змогу вчителю поступово підвищувати рівень володіння компетентністю у сорері охорони і захисту прав інтелектуальної власності.

Ключові слова: підвищення квалісрікації, інтелектуальна власність, загальна середня освіта, заклад загальної середньої освіти, працівник закладу загальної середньої освіти.

The article analyzes the current trends in the process of professional development of teachers of general secondary education in terms of diversification of educational services after the update of legislation in the field of education. Attention is paid to the peculiarities of professional development of pedagogical workers in the field of protection and enforcement of intellectual property rights for the formation of professionally significant competence. The need for the formation of competence in the field of protection and enforcement of intellectual property rights, which will allow teachers to conduct professional activities at a high level in compliance with current legislation on copyright and related rights, ensure compliance with academic integrity during the educational process and protect copyright creative activity and research activity of students. A conceptual model of in-service training of teachers of general secondary education institutions in the field of intellectual property is presented, taking into account modern educational challenges, society's requirements for the professional level of teachers and the modular principle of in-service training plans. Possible ways to improve the skills of teachers in the field of intellectual property are highlighted. It was found that the mobility of teachers in choosing the content of plans and the choice of training institutions allows you to rationally allocate time to fill gaps in the protection and enforcement of intellectual property rights in secondary education. The application of the technological approach to professional development in the outlined field is substantiated and the "Technology of formation of competence in the field of protection and protection of intellectual property rights of teachers in the process of professional development" is given. It is established that for effective pedagogical activity it is necessary to form professionally significant competence in the field of protection and protection of intellectual property rights throughout the professional development of teachers, which allows teachers to gradually increase the level of competence in protection and protection of intellectual property rights.

Key words: advanced training, intellectual property, general secondary education, genera secondary education institution, employee of general secondary education institution. Української інженерно-педагогічної академії

Постановка проблеми в загальному вигляді. На сучасному етапі розвитку система загальної середньої освіти України потребує постійного оновлення методів, прийомів, підходів, засобів та технологій для забезпечення якісного навчання здобувачів освіти. Така тенденція спричиняє потребу суспільства в учителях, які можуть задовольняти вимоги ринку освітніх послуг, уміють взаємодіяти з різними групами учнів, $є$ конкурентоспроможними та можуть творчо підходити до здійснення викладацької діяльності. Сучасні вчителі повинні під час своєї професійної та дослідницької діяльності розробляти інтелектуальні продукти, що підпадають під охорону та захист авторських прав згідно 
3 чинним законодавством. Проте спроможність педагогічних працівників ланки загальної середньої освіти здійснювати правовий захист результатів власної творчої праці знаходиться на низькому рівні. Це зумовлено прогалинами чинного законодавства у галузі інтелектуальної власності, низьким рівнем правової культури суспільства, відсутністю зацікавленості вчительської спільноти у здійсненні захисту та охорони авторських і суміжних прав тощо.

Упровадження концепції «Нова українська школа», прийняття законів України «Про освіту» від 5 вересня 2017 р. № 2145-VIII та «Про повну загальну середню освіту» від 16 січня 2020 р. № 463-ІХ., Наказу МОНУ «Концепція розвитку педагогічної освіти» від 16 липня 2018 р. № 776, постанов Кабінету Міністрів України «Деякі питання підвищення кваліфікації педагогічних і науково-педагогічних працівників» від 21.08.2019 № 800 та «Про внесення змін до Порядку підвищення кваліфікації педагогічних і науково-педагогічних працівників» від 27.12.2019 № 1133 поставило на порядок денний питання стосовно рівня професійної майстерності вчителя закладу загальної середньої освіти та його професійної перепідготовки згідно 3 нагальними потребами суспільства. Окреслені нормативні акти висунули низку вимог стосовно введення інновацій в освітній процес шляхом створення оригінальних розробок, створення інтелектуального продукту як результату підвищення кваліфікації, ведення професійної діяльності на засадах академічної доброчесності, але пояснення, як задовольнити вимоги, висунуті у законодавчих актах, відсутнє. Тобто актуальним став пошук шляхів вирішення питання невідповідності сучасного стану розвитку системи педагогічної освіти та потреби суспільства у висококваліфрікованих педагогічних кадрах, що повинно вирішуватися під час проходження вчителями підвищення кваліфікації, у тому числі й у галузі охорони і захисту прав інтелектуальної власності.

Аналіз останніх досліджень і публікацій. Загальні питання підвищення кваліфрікації вчителів висвітлено в роботах Н. Білик, Н. Євтушенко, В. Лунячека, С. Пакуліна, В. Швидуна, В. Сидоренко, І. Смагіна та ін.

Зокрема, Н. Євтушенко зазначив, що гуманізація освітнього процесу повинна бути провідною ідеєю підвищення кваліфрікації вчителя, за мету означеного процесу автор уважає створення педагогічних умов для «виконання замовлення суспільства на рівень та якість підготовки кваліфікованих педагогічних кадрів» [3, с. 35].

Н. Білик висловилася стосовно спрямованості підвищення кваліфікації в Україні на здобуття додаткових професійних знань, умінь та навичок із базового предмету та вдосконалення певних професійних якостей учителя. Авторка акцентує увагу на необхідності посилення зв'язків між роботою закладів післядипломної освіти та нагальними потребами суспільства у кваліфрікованих педагогічних кадрах [1].

Необхідність переходу системи підвищення кваліфрікації педагогів до єдиного механізму переорієнтації вчителів стосовно системи ціннісних орієнтирів, змісту та форм навчання висвітлено в роботі В. Швидуна [16].

В. Лунячек зазначає, що в нових умовах диверсифрікації освітніх послуг із підвищення кваліфікації повільно розвивається методологія процесу пізнання. Це відбувається через неготовність 3ВО, що здійснюють підвищення кваліфікації педагогів, до активних змін у системі післядипломної освіти; утрату інститутами післядипломної педагогічної освіти частини слухачів модулей підвищення кваліфрікації; відсутність наукового потенціалу у інших суб'єктів підвищення кваліфікації для розроблення нових алгоритмів та моделей підвищення квалісрікації педагогів; неспроможність керівників З3СО оцінити результати підвищення кваліфікації педагогічних працівників [9].

У роботі І. Смагіна увага приділяється підходам до визначення якості надання освітніх послуг із підвищення квалісрікації. Автор указує, що критерії якості підвищення кваліфікації можуть бути визначені на основі нормативно-правової бази або безпосередньо особою, яка отримує освітні послуги, на основі власних вражень від роботи їх надавача. У цьому контексті виникає проблема нерівності умов визнання результатів підвищення квалісрікації на основі ліцензування, під час акредитації освітньої програми, на підставі рішення педагогічної ради закладу освіти [15].

Окремо необхідно звернути увагу на колективну монографрію «Компетентнісний вимір профресійного розвитку працівників освіти у сорері інтелектуальної власності», автори якої опрацювали окремі теоретико-методичні аспекти підвищення кваліфікації працівників освітньої сфрери у галузі інтелектуальної власності, акцентували увагу на дотриманні норм академічної доброчесності під час освітнього процесу в 3СО та обґрунтували необхідність підвищення кваліфікації вчителів у галузі інтелектуальної власності. В окресленій монографії представлено результати наших попередніх досліджень стосовно питань захисту об'єктів інтелектуальної власності в 33СО та академічній доброчесності як складовій частині внутрішнього забезпечення якості освіти в 33СО [4, с. 136-146, 173-182].

Виділення не вирішених раніше частин загальної проблеми. Підвищення кваліфікації вчителів закладів загальної середньої освіти в галузі інтелектуальної власності довгий час не було пріоритетним напрямом через відсутність інтересу педагогічних працівників до планів 
даного спрямування. 3 оновленням законодавства питання охорони і захисту прав інтелектуальної власності в закладах загальної середньої освіти стають усе більш актуальними, що зумовлює необхідність теоретико-методологічного обґрунтування процесу підвищення кваліфрікації вчителів 33СО в окресленій галузі.

Мета статті. Метою статті є теоретико-методологічне обґрунтування особливостей процесу підвищення кваліфікації вчителів закладів загальної середньої освіти у сфері охорони і захисту прав інтелектуальної власності.

Виклад основного матеріалу. Згідно зі ст. 59 Закону України «Про освіту» та ст. 54 Закону України «Про повну загальну середню освіту», профресійний розвиток педагогів включає у себе постійну самоосвіту та самовдосконалення, участь у програмах підвищення кваліфрікації та інші форми діяльності, що спрямовані на професійне зростання. Підвищення кваліфрікації є необхідним під час подальшої атестації педагога (присудження звання або категорії) та враховується під час конкурсного відбору на посаду науково-педагогічних працівників.

Процес підвищення кваліфікації вчителів 33СО має декілька організаційних етапів, а саме:

1) обговорення можливих видів і фрорм підвищення кваліфрікації;

2) оголошення атестаційною комісією закладу середньої освіти мінімальної кількості годин підвищення кваліфікації, які необхідно набрати вчителям протягом року;

3) визначення особистої траєкторії підвищення кваліфрікації для кожного вчителя;

4) формування та затвердження педагогічною радою закладу середньої освіти щорічного плану підвищення кваліфікації;

5) проходження педагогічними працівниками підвищення кваліфікації у зручній фрормі;

6) надання вчителями сертифрікатів про проходження підвищення кваліфікації атестаційній коміciї 33СО [2; 13].

Згідно із Законом України «Про освіту» та Постановою КМУ від 21.08.2019 № 800, у процесі підвищення кваліфікації вчитель повинен прослухати за накопичувальною системою протягом п'яти років не менше 150 годин із предмету, який він викладає, і курсів, що мають впливати на фрормування його професійної компетентності. Основна кількість педагогічних працівників проходить підвищення кваліфікації на базі інститутів післядипломної педагогічної освіти за класичною схемою, у навчальних планах яких не передбачено висвітлення тем із захисту інтелектуальної власності працівників загальної середньої освіти [2; $9 ; 10 ; 13]$.

Питання фрормування компетентності у сорері охорони та захисту прав інтелектуальної влас- ності шляхом підвищення кваліфрікації актуалізували ст. 42 Закону України «Про освіту», де однією 3 норм академічної доброчесності в закладі освіти $€$ дотримання законодавства у сорері інтелектуальної власності, і Наказ МОНУ від 15.01.2018 № 36 «Про затвердження Типової освітньої програми організації і проведення підвищення кваліфікації педагогічних працівників закладами післядипломної педагогічної освіти», де вказано, що підвищення кваліфікації вчителів передбачає такий складник, як «захист авторських розробок ... видача документів», але конкретний опис передбачуваних результатів навчання відсутній [10; 12; 13].

Наголосимо, що носіями інфрормації щодо механізмів захисту прав інтелектуальної власності $€$ не дуже численні кафедри вищих навчальних закладів різного спрямування, а саме: кафедра інтелектуальної власності Інституту права Київського національного університету ім. Т.Г. Шевченка (2013р.), кафедра інтелектуальної власності та цивільно-правових дисциплін Київського інституту інтелектуальної власності та права НУ «ОЮА» (2010р.), Науково-дослідний інститут інтелектуальної власності Національної академії правових наук України, кафредра інфрормаційного права та інтелектуальної власності Київського політехнічного інституту ім. Ігоря Сікорського (2013 р.), кафредра інтелектуальної власності та управління проєктами Національної металургійної академії України (2018р.), кафредра інфрорматики та інтелектуальної власності НТУ «ХПІ» (1999 р.), кафедра економічної теорії, інтелектуальної власності та публічного управління Поліського національного університету (2001 р.), кафедра креативної педагогіки і інтелектуальної власності Української інженерно-педагогічної академії (1998р.), кафедра інтелектуальної власності Черкаського національного університету ім. Б. Хмельницкого (2006 р.). Не всі зазначені кафедри працюють 3 учителями, а ті, що мають плани з підвищення кваліфікації для педагогів закладів середньої освіти, не можуть охопити всю вчительську спільноту України, що свідчить про десіцит фрахівців відповідного спрямування. Зокрема, досвід кафедри креативної педагогіки і інтелектуальної власності УІПА вказує на наявність проблем із масовим охопленням педагогічних працівників і керівників освіти в роботі за зазначеним напрямом, що призвело до висновку щодо необхідності підготовки тренерів для кожного районного управління освіти за спеціальною програмою підвищення кваліфікації педагогічних працівників у сорері інтелектуальної власності.

Підвищення кваліфікації у галузі інтелектуальної власності доцільно представити у вигляді концептуальної моделі, представленої на рис. 1. 


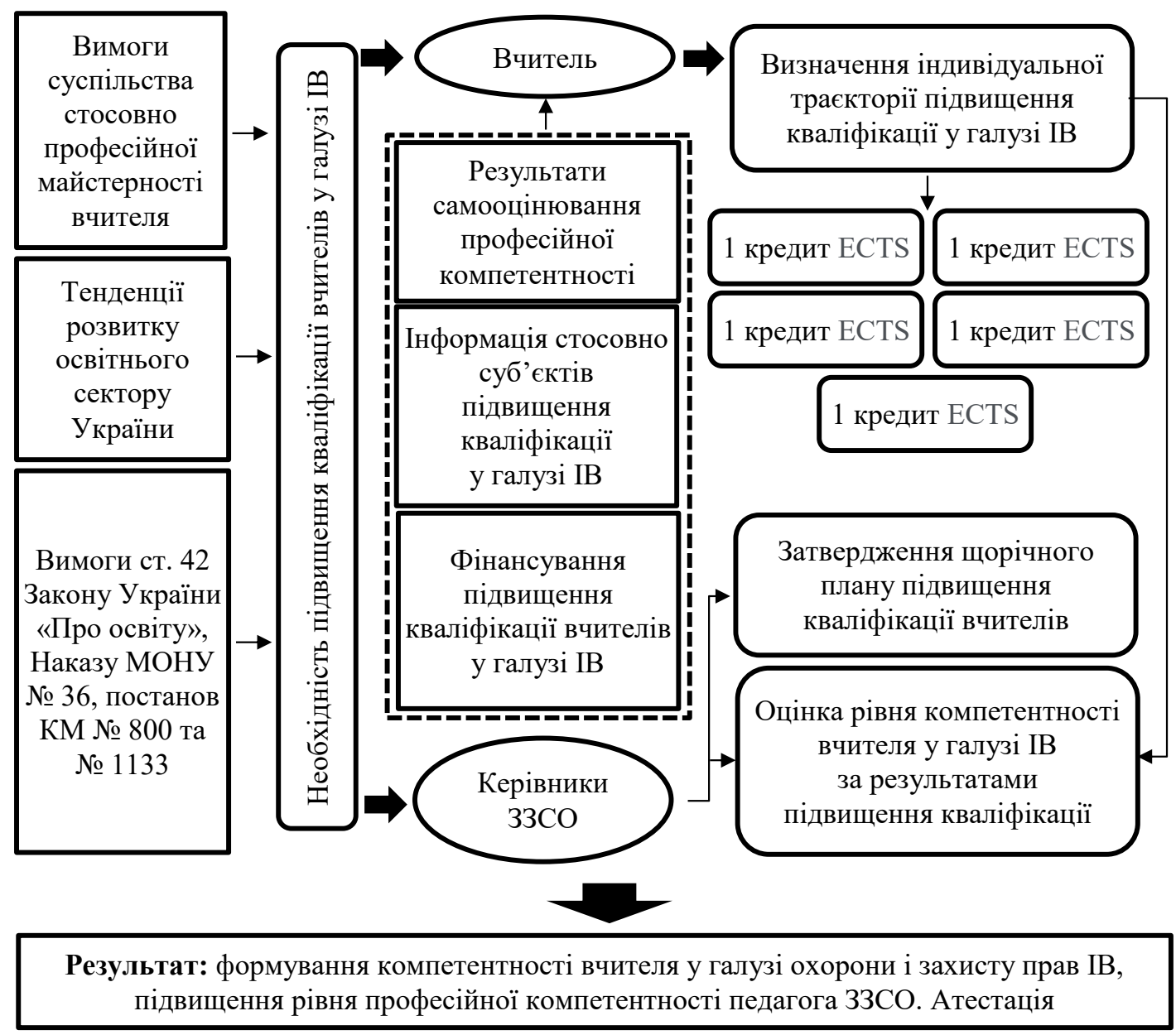

Рис. 1. Концептуальна модель підвищення кваліфікації вчителів 3зсо у галузі інтелектуальної власності

Під час її побудови було приділено увагу потребам суспільства у кваліфікованих педагогах, вимогам чинного законодавства стосовно необхідності створення інтелектуальних продуктів під час підвищення кваліфікації та дотримання норм академічної доброчесності під час освітнього процесу (одним із пунктів ст. 42 Закону України «Про освіту» $€$ дотримання законодавства у сорері інтелектуальної власності). Ураховано модульний принцип підвищення квалісікації, що дає змогу будувати плани, спираючись на особисті потреби кожного вчителя.

За наведеною моделлю підвищення кваліфікації вчителів 33СО у галузі інтелектуальної власності може відбуватися різними шляхами, а саме:

1) шляхом додавання коротких змістовних модулей з актуальних питань охорони і захисту прав IB у діючі навчальні плани з підвищення квалісрікації;

2) шляхом проведення виїзних спецкурсів у закладах середньої освіти;

3) шляхом проходження повноцінного підвищення кваліфрікації тривалістю 150 годин [8]. Така мобільність у виборі шляху підвищення квалісікації у галузі IB дає змогу вчителю вибрати тільки ті змістовні блоки, які йому знадобляться у подальшій професійній діяльності, та більш раціонально розподілити час, який відведено на підвищення квалісрікації.

Педагогічні працівники 33СО в умовах диверсисрікації освітніх послуг після 2017 р. можуть підвищувати кваліфікацію у закладах вищої освіти, інститутах післядипломної освіти, у закладах, які мають ліцензію на проведення підвищення кваліфікації або акредитовану навчальну програму, інших освітніх установах або на онлайн-платформах (таке підвищення кваліфрікації може бути затверджене рішенням педагогічної ради). Така ситуація спрощує формування індивідуальної освітньої траєкторії вчителя та дає змогу розширити коло професійних інтересів учительського загалу, що сприяє виникненню зацікавленості у формуванні компетентності у галузі охорони і захисту прав IB як нагальної потреби інсрормаційного суспільства.

Як ми зазначали у наших попередніх роботах для успішного підвищення кваліфікації вчителів 33СО у галузі охорони і захисту прав інтелектуальної власності доцільно застосовувати технологічний підхід для формування професійно важливої 
компетентності у галузі IB. Він полягає у побудові зв'язків між навчанням і конкретною профресійною діяльністю з урахуванням мети, мотивації та потреб кожного окремого вчителя. Позитивною рисою його застосування для організації підвищення квалісрікації у галузі охорони і захисту прав IB $€$ його послідовність, тобто наявність системи чітко визначених кроків, які ведуть до досягнення кінцевої мети навчання.

Нами було розроблено та теоретично обґрунтовано «Технологію соормування компетентності у сорері охорони та захисту прав інтелектуальної власності вчителів у процесі підвищення кваліфрікації», яка спрямована на:

1) формування у вчителя сукупності знань стосовно нормативно-правового забезпечення у сорері IB, джерел виникнення прав інтелектуальної власності, системи інтелектуальної власності України, міжнародного співробітництва у галузі IB, об'єктів IB у школі, видів охоронних документів на об'єкти IB, дотримання норм академічної доброчесності під час навчального процесу;

2) формування вмінь та навичок з оформлення охоронних документів на власні інтелектуальні твори і результати креативної діяльності обдарованих учнів та здійснення судового захисту власних авторських прав;

3) зміну сприйняття результатів творчої діяльності вчителя як економічного продукту, який може приносити певну користь і $€$ об'єктом охорони та захисту права інтелектуальної власності;

4) формування розуміння сутності і процедури трансферу технологій в освіті, необхідності його здійснення;
5) забезпечення дотримання норм та правил академічної доброчесності під час ведення викладацької діяльності;

6) розуміння сутності інтелектуального продукту в системі освіти, необхідності його створення та управління результатами творчої діяльності вчителів 3СО [6; 7].

Вище наведена технологія дає змогу сформувати професійно значущу компетентність у сфері охорони і захисту прав IB, яка необхідна для забезпечення дотримання норм академічної доброчесності під час освітнього процесу та комерціалізації результатів інноваційної діяльності вчителів та учнів.

Необхідно визначити, на якому етапі професійного розвитку педагога доцільно фрормувати компетентність у сфері охорони і захисту прав інтелектуальної власності.

Формування професійних компетентностей педагога починається після вибору предметної галузі під час навчання у профрільному ЗВО або коледжі. Перші професійно значущі знання та вміння вчитель отримує під час проходження педагогічної практики, де остаточно визначається 3 напрямом майбутньої професійної діяльності. Далі відбувається поступовий професійний розвиток учителя за схемою, представленою на рис. 2.

Формування професійних компетентностей учителя відбувається паралельно 3 процесом навчання впродовж життя, постійним підвищенням кваліфікації та проходженням атестації, щоб довести відповідність рівня профресійної майстерності займаній посаді та наявній кваліфікаційній категорії. Фактично під час підготовки молодого

адаптація молодого фахівця до професійної діяльності - отримання категорії «спеціаліст»

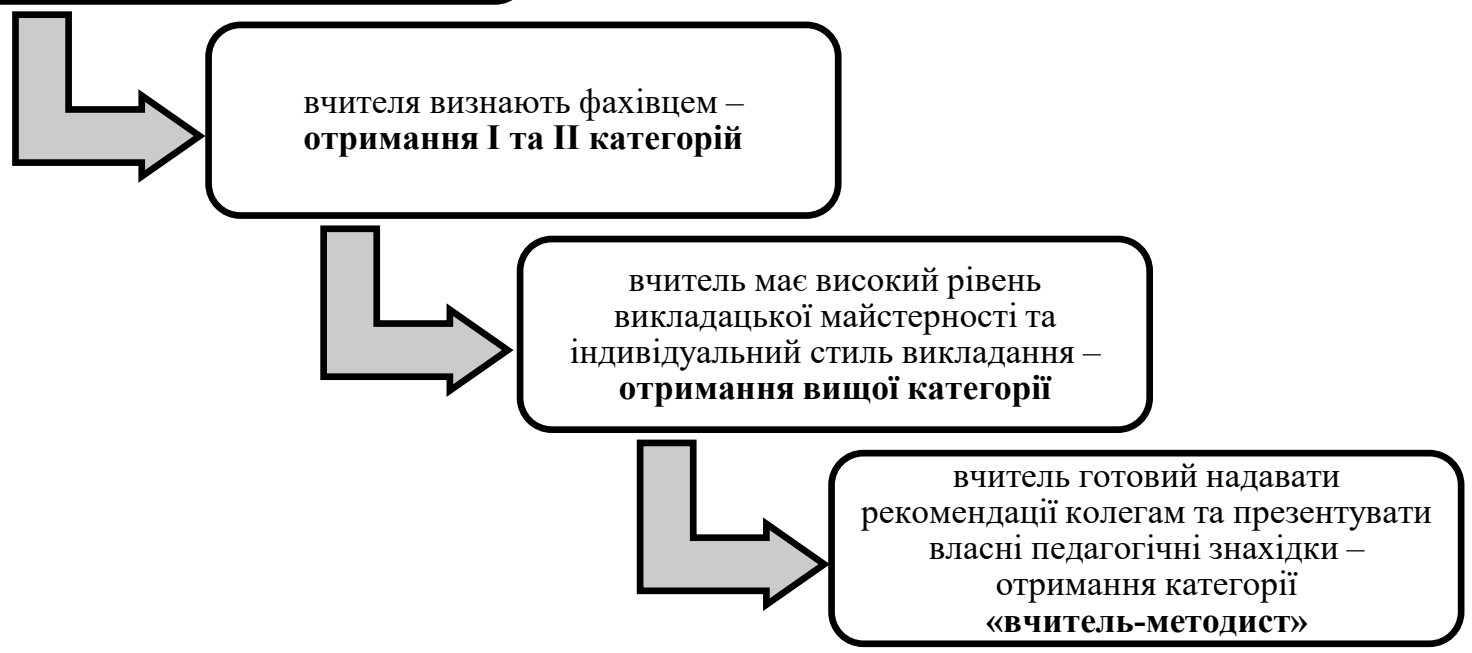

Рис. 2. Професійний розвиток учителя 
вчителя необхідно сорормувати початкове розуміння фрункціонування системи інтелектуальної власності України та звернути особливу увагу на проблемні питання IB в освіті. Під час набуття молодим учителем певного педагогічного стажу та професійного досвіду потрібно поглиблювати знання стосовно об'єктів інтелектуальної власності в 3СО, управління ними, питань дотримання норм академічної доброчесності, трансореру освітніх технологій та ін.

Висновки. У процесі нашого дослідження було визначено закономірності процесу підвищення кваліфікації педагогічних працівників 33СО у сорері охорони і захисту прав IB:

1) ефрективність процесу підвищення кваліфрікації вчителів 33СО в Україні згідно із сучасними тенденціями розвитку освітнього сектору залежить від сорормованості окремих професійно значущих компетентностей;

2) ефрективність процесу підвищення кваліфікації вчителів 33СО у сфрері охорони і захисту прав інтелектуальної власності визначається коректним застосуванням компетентісного та технологічного підходів для забезпечення комплексності навчання;

3) результативність процесу підвищення квалісікації вчителів 3ЗСО залежить від змістовного наповнення окремих планів підвищення кваліфікації та кількості годин, які на них відведені;

4) ґрунтовно розроблена педагогічна технологія забезпечує досягнення високих результатів після проходження планів підвищення кваліфікації вчителями.

\section{БІБЛІОГРАФІЧНИЙ СПИСОК:}

1. Білик Н.І. Підвищення кваліфрікації як механізм неперервного розвитку професійної мобільності вчителя. URL: https://www.unesco-journal.com.ua/ index.php/journal/article/view/16/15 (дата звернення: 26.02.2021).

2. Деякі питання підвищення кваліфікації педагогічних і науково-педагогічних працівників : Постанова Кабінету Міністрів від 21 серпня 2019 р. № 800. URL: https://zakon.rada.gov.ua/laws/show/800-2019\%D0\%BF\#n114 (дата звернення: 04.02.2021).

3. Євтушенко Н.В. Цілі та завдання підвищення квалісікації вчителів природничо-математичних предметів в умовах ресрормування освіти України. Science and Education a New Dimension. Pedagogy and Psychology. 2018. № VI(72). Issue 174. C. 35-38.

4. Компетентнісний вимір профресійного розвитку працівників освіти у сфері інтелектуальної власності : монографрія / В.Е. Лунячек та ін. ; за заг. ред. В.Е. Лунячека. Харків : Оберіг, 2020. 368 с.

5. Концепція розвитку педагогічної освіти в Україні : Наказ МОНУ від 16 липня 2018 р. № 776. URL: https://mon.gov.ua/ua/npa/pro-zatverdzhennyakoncepciyi-rozvitku-pedagogichnoyi-osviti (дата звернення: 04.08.2020).
6. Кравчук Н.Л. Реалізація технологічного підходу до підвищення кваліфікації вчителів у галузі інтелектуальної власності. Міждисциплінарні наукові дослідження: особливості та тенденції : матеріали міжнародної наукової конфреренції, 4 грудня 2020 р. Чернігів : МЦНД, 2020. Т. 4. С. 62-63.

7. Кравчук Н.Л. Технологія фрормування компетентності у ссрері охорони та захисту прав інтелектуальної власності вчителів у процесі підвищення квалісрікації. Витоки педагогічної майстерності. 2020. № 26. C. 125-137.

8. Лунячек В.Е., Рубан Н.П. Формування у працівників закладів загальної середньої освіти в процесі підвищення квалісрікації компетентності щодо захисту прав 3 інтелектуальної власності. Проблеми інженерно-педагогічної освіти. 2019. № 63. С. 16-28.

9. Лунячек В.Е. Моделі та алгоритми підвищення кваліфікації працівників освіти в умовах диверсисрікації освітніх послуг. Проблеми інженерно-педагогічної освіти. 2020. № 66. C. 5-20. URL: http:// repo.uipa.edu.ua/jspui/bitstream/123456789/6309/1/3. pdf (дата звернення: 20.03.2021).

10. Навчати і навчатися: як і куди зростати українському вчительству? Результати дослідження сорери підвищення кваліфікації й сертифрікації у рамках спільної ініціативи руху EdCamp Ukraine і Міністерства освіти і науки України / О. Елькін та ін. Харків : Дім Реклами, 2019. 120 с.

11. Про внесення змін до Порядку підвищення кваліфікації педагогічних і науково-педагогічних працівників : Постанова Кабінету Міністрів від 27 грудня 2019 р. № 1133. URL: https://zakon.rada.gov.ua/laws/ show/1133-2019-\%D0\%BF\#Text (дата звернення: 04.08.2020).

12. Про затвердження Типової освітньої програми організації і проведення підвищення кваліфрікації педагогічних працівників закладами післядипломної педагогічної освіти : Наказ Міністерства освіти і науки України від 15 грудня 2018 р. № 36. URL: $\quad$ https://imzo.gov.ua/2018/01/16/nakaz-mon-vid15-01-2018-36-pro-zatverdzhennya-typovoji-osvitnojiprohramyorhaniza tsiji-i-provedennya-pidvyschennyakvalifikatsiji-pedahohichnyhpratsivnykiv-zakla damy-pislyadyplomnoji-pedahohichn/ (дата звернення: 25.02.2021).

13. Про освіту : Закон України від 5 вер. 2017 р. № 2145-VIII. URL: https://zakon.rada.gov.ua/laws/ show/2145-19\#Text (дата звернення: 04.08.2020).

14. Про повну загальну середню освіту : Закон України від 16 січ. 2020 р. № 463-IX. URL: https:// zakon.rada.gov.ua/laws/main/463-20\#Text (дата звернення: 04.08.2020).

15. Смагін І.І. Якість освітніх послуг з підвищення кваліфрікації: визначення поняття 3 позицій діяльнісно-срункціонального підходу. Науковий вісник ужгородського університету. Серія «Педагогіка. Соціальна робота». 2020. Вип. 2(47). С. 171-175.

16. Швидун В.М. Управління післядипломною педагогічною освітою як складовою освіти в Україні. Нова педагогічна думка. 2019. № 3(99). С. 48-51. 